\title{
Cell proliferation and migration in the jejunum of suckling rats submitted to progressive fasting
}

J.R. Gomes and E.P. Alvares

\author{
Departamento de Histologia e Embriologia, Instituto de Ciências Biomédicas, \\ Universidade de São Paulo, São Paulo, SP, Brasil
}

\begin{abstract}
Correspondence

E.P. Alvares

Av. Prof. Lineu Prestes, 1524 05508-900 São Paulo, SP Brasil

Fax: 55 (011) 818-7402

Presented at the 5th International Symposium on Radioautography, São Paulo, SP, Brasil,

August 24-26, 1997.

Research supported in part by FAPESP.J.R. Gomes was the recipient of a CAPES fellowship. .........................

Received September 23, 1997 Accepted November 3, 1997

Cell proliferation and migration in the intestinal crypts, and cell migration in the villus are controlled by different mechanisms in adult rats. In the present study, weanling rats and fasting rats were used to quantitatively study the correlation of cell cycle parameters and epithelial cell migration in crypts and intestinal villi. Eighteen-day-old rats received a single injection of tritiated thymidine $\left[{ }^{3} \mathrm{H}\right] \mathrm{TdR}(23: 00$ h); half of the pups were submitted to fasting $5 \mathrm{~h}$ earlier. Cell proliferation was determined in radioautographs of jejunal crypts, on the basis of the labeling indices (LI) taken 1, 8, 13 and $19 \mathrm{~h}$ after $\left[{ }^{3} \mathrm{H}\right] \mathrm{TdR}$. The results showed that the labeling index did not differ $1 \mathrm{~h}$ or $19 \mathrm{~h}$ after $\left[{ }^{3} \mathrm{H}\right] \mathrm{TdR}$ between the fed $(38.7 \%$ or $48 \%)$ and fasting groups $(34.6 \%$ or $50.4 \%)$. The modified method of grain count halving indicated that cell cycle time did not differ between fed (16.5 h) and fasting rats $(17.8 \mathrm{~h})$; the growth fraction, however, had lower values in fasting (59\%) than in fed rats $(77 \%)$. Cell migration in the crypt, estimated by the LI obtained for each cell position, did not change with treatment. As for the villi, the cell migration rate was significantly retarded by 3 cell positions $(8 \%)$. These results suggest that the cell migration in the villi of weanling pups does not depend directly on the cell proliferation and migration in the intestinal crypt, but is directly affected by the absence of food in the lumen.
\end{abstract}

\section{Key words}

- Cell proliferation

- Cell migration

- Crypt and villus intestine

- Weanling rats

- Radioautography

\section{Introduction}

The epithelium that covers the intestinal mucosa undergoes constant renewal and the cells produced in the crypts migrate into the villi, being lost at their tips. The investigations on the mechanisms involved in the migration of these cells and its correlation with proliferation have been mostly concerned with adult animals. It was suggested that cell migration is achieved via two separate mechanisms, one acting in the crypt and requiring protein synthesis, and the other, more passive, operating in the villus (1). It was also demonstrated that cell migration, both within the crypt and the villi, is not dependent on mitotic activity in adult rats (2).

In suckling rats, the migration of intestinal cells is extremely slow when compared to weaned and adult rats $(3,4)$. During the weaning period, especially between 18 and 19 days, there is an acceleration of the cell migration rate in the small intestine (5). Also, during the weaning period the cell migration of the rat is paralleled by increased enzymatic activities mainly of maltase and sucrase in the functional cells covering the villi (6). Intestinal growth is also accelerated during weaning (7). Despite its importance for the growth and maintenance of intestinal 
weight, the role of luminal nutrition has not been ascertained. The change in diet that progressively occurs during weaning was considered unlikely to play a role in the acceleration of cell migration rate (5).

Recently we have demonstrated that fasting decreases cell proliferation in all segments of the small intestine of suckling pups, but regional variations occur in weanling rats. In the jejunum, for instance, there is no difference in proliferative indices between fed and fasting rats (8). However, the villus height was shortened in suckling and weanling rats, and therefore a delay in cell migration was suggested (8).

The importance of this critical period of intestinal growth makes it a suitable model to investigate the relationship between proliferation in the crypts and migration to the villus tip, using fasting weanling rats and radioautographic methods of cell and tissue kinetics.

\section{Material and Methods}

\section{Experimental design}

Weanling Wistar rats (ICB, USP) aged 18 days were maintained at $20^{\circ} \mathrm{C}$ on a natural light-dark cycle. At 17 days, rats were separated into control and experimental groups. The latter group was fasted continuously for $24 \mathrm{~h}$ starting at 18:00 h, but was allowed free access to water. Control rats were kept with their mothers throughout the experiment. Five hours later $(23: 00 \mathrm{~h})$ control and fasting rats received a single ip injection of $\left[{ }^{3} \mathrm{H}\right]$-methylthymidine $\left(\left[{ }^{3} \mathrm{H}\right] \mathrm{TdR}\right)$ at a dose of $1 \mu \mathrm{Ci} / \mathrm{g}$ body weight (specific activity $45 \mathrm{Ci} / \mathrm{mM}$; Amersham, UK). Three to six rats from each group were killed by ether inhalation at 1,8 , 13 and $19 \mathrm{~h}$ after the injection of $\left[{ }^{3} \mathrm{H}\right] \mathrm{TdR}$.

The small intestine was dissected, freed from the mesentery and flushed with saline. A fragment at least $2 \mathrm{~cm}$ in length was taken from the middle portion of the jejunum, opened longitudinally on a card and fixed in
Carnoy's fluid for $6 \mathrm{~h}$. Smaller fragments were dehydrated and embedded in hydroxyethyl methacrylate (Kulzer, Germany). Two$\mu \mathrm{m}$ sections mounted on slides were dipped in $\mathrm{K}_{2}$ liquid emulsion (dilution 1:1; Ilford, Essex, UK) and stored at $4^{\circ} \mathrm{C}$ in lightproof boxes (9). The time of exposure was determined from the best curve fitting the distribution of grain counts over nuclei. The number of grains in 50 nuclei per rat, in 3 fed rats, was counted in crypts longitudinally cut of radioautographs exposed for $10,15,20$ or 25 days. After the appropriate exposure time, the radioautographs were developed with D19B (Kodak), fixed and stained with hematoxylin and eosin.

\section{Proliferative indices}

The DNA synthetic index (determined 1 $\mathrm{h}$ after $\left[{ }^{3} \mathrm{H}\right] \mathrm{TdR}$ injection by pulse labeling) and labeling index (determined 8, 13 and 19 $\mathrm{h}$ after $\left[{ }^{3} \mathrm{H}\right] \mathrm{TdR}$ injection), both referred to here as labeling index (LI), were obtained for fed and fasting rats. Cell counts were scored in selected longitudinally sectioned crypts showing a lumen. Growing (too short) or bifurcating crypts were not considered. About 1,500 cells per animal were counted. The LI was expressed as the percentage of labeled nuclei in the total number of nuclei counted. Five grains were the minimum for a labeled cell to be counted.

\section{Estimation of cell migration in the crypts}

In each crypt, the left-hand column of cells was numbered, counting from the bottom up to the crypt-villus junction. For each cell position the presence or absence of labeling was recorded ( 5 grains or more) in 20 crypts per animal. The LI was thus estimated for each cell position for each group of animals at each time of sacrifice. Labeling index distribution curves were obtained, in which LI were plotted as a function of cell position in the crypt (10). 
The variation in the height of the crypt columns was compensated for by analyzing the data also after standardization. Each crypt was divided into 3 regions, bottom, middle and top, as follows: the middle of the crypt contained a fixed number of 6 cells; the bottom and the top contained the other cells in a more variable number.

\section{Morphometric measurements}

Two morphometric parameters were obtained for the crypts: the length of the crypt column in terms of cell number measured as described above, and the column count, in which the number of cells was determined using 12 crypt cross-sections in each animal. The product of the crypt column length and the column count gives an estimation of the total crypt population (11).

\section{Estimation of cell cycle and growth fraction}

The parameters of the cell cycle were obtained using a modification of the grain count halving method (12). In each cell division, i.e., after each cell cycle, the labeled DNA of the mother cell is distributed quite uniformly between the two daughter cells. Therefore, the mean grain number per nucleus is reduced roughly to half its value. In the modification of this method, we determined the mean grain number of all cells in the crypts (labeled and unlabeled) at different times after $\left[{ }^{3} \mathrm{H}\right] \mathrm{TdR}$ injection $(1,8,13$ and $19 \mathrm{~h}$ ). Linear regressions can be derived from the reduction of the mean grain number as a function of time after pulse labeling. The decrease in mean grain number for all interphase cells, in addition to that of all labeled interphase cells, will provide the cycle time of the cell population (Tc) and the potential doubling time (Tpot). The growth fraction, the fraction of crypt cells engaged in the cell cycle, is derived from $\mathrm{G}=2^{\mathrm{Tc} / \mathrm{Tpot}}-1$ (12). The error of the growth fraction was estimated from the errors of Tc and Tpot, as de- scribed by Bassukas and Schultze-Maurer(12).

\section{Estimation of cell migration in the villus}

The leading edge of labeled cells along the villus and the total number of villus cells were determined in four rats. For each rat, analyses were carried out on 30 villi, each showing a continuous epithelium from villus tip to the base of the crypt. Cell migration is reported as the percentage of villus height occupied by labeled cells $19 \mathrm{~h}$ after $\left[{ }^{3} \mathrm{H}\right] \mathrm{TdR}$ injection. The cell migration rate was calculated from the position of leading-labeled cells in the villus divided by the time elapsed after labeling (13).

\section{Statistical analysis}

Data are reported as means \pm SD. Differences between fed and fasting groups were determined by the Student $t$-test. Withingroup differences were tested by one-way analysis of variance (ANOVA) and when the ANOVA results were significant, data were further analyzed by the Tukey test, with the level of significance set at $\mathrm{P}<0.05$. The slopes of linear regressions were compared by the Student $t$-test (14). The KolmogorovSmirnov test was used to analyze the normal distribution of grains in order to determine the best exposure time (15).

\section{Results}

\section{Determination of time of exposure and labeling indices}

The distribution of grains per nucleus for the radioautographs exposed for 10, 15, 20 and 25 days was analyzed by the Kolmogorov-Smirnov test and the best fit was found after 20 days of exposure. The exposure time was set at 20 days in all experiments.

No morphological differences in the intestines were observed between groups. Visual inspection of radioautographs of fasting and 
Figure 1 - Radioautograph of the jejunum of a fed weanling rat, 1 $h$ after injection of $\left[{ }^{3} \mathrm{H}\right] \mathrm{TdR}$. Crypts showing well-labeled nuclei (arrow); crypt-villus junction (CV). Magnification: 560X.

Figure 2 - Radioautograph of the jejunum of a fed weanling rat, 19 $h$ after injection of $\left[{ }^{3} \mathrm{H}\right] \mathrm{TdR}$. Villi showing labeled nuclei (arrow); crypt-villus junction (CV). Magnification: 837X. fed rats showed no difference between groups. The crypts were labeled after the first injection of $\left[{ }^{3} \mathrm{H}\right] \mathrm{TdR}$ (Figure 1) and the villi showed labeled cells $13 \mathrm{~h}$ after $\left[{ }^{3} \mathrm{H}\right] \mathrm{TdR}$ injection in both fed and fasting rats (Figure 2). The crypts of the jejunum of fed and fasting weanling rats contained about 200 cells with
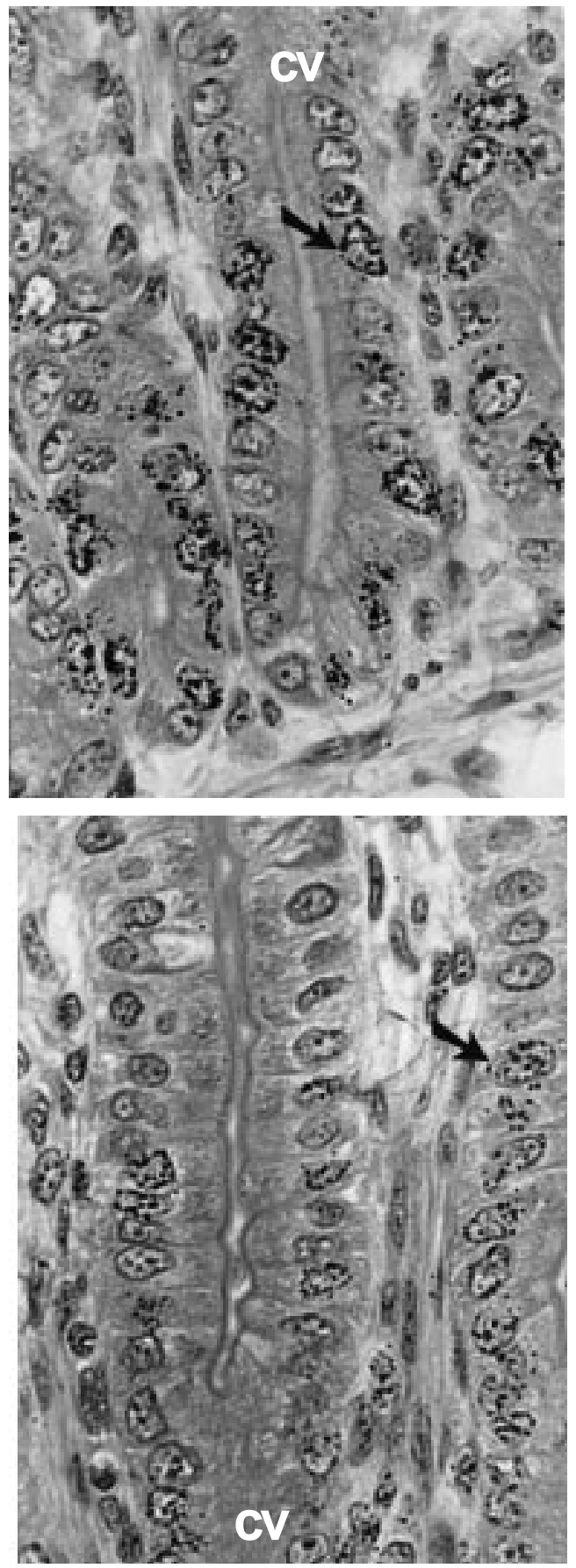

11-12 cells in the column count and about 17-18 cells in the column crypt.

The LI were not significantly different between fed and fasting rats at any interval studied (Table 1). LI increased with time, indicating that some cell division had occurred. The post-ANOVA test inside the groups showed a significant difference in LI at $13 \mathrm{~h}$ for the fed rats and at $19 \mathrm{~h}$ for the fasting rats compared to the LI at pulse labeling, i.e., $1 \mathrm{~h}$ after $\left[{ }^{3} \mathrm{H}\right] \mathrm{TdR}$ (Table 1 ). This difference indicates a delay in the fasting group.

\section{Migration in the crypt}

The migration of epithelial cells along the length of the crypt was studied by two methods at the various time intervals. The counting of labeled cells per cell position at $1,8,13$ and $19 \mathrm{~h}$ after $\left[{ }^{3} \mathrm{H}\right] \mathrm{TdR}$ injection produced the labeling index distribution curves illustrated in Figure 3. There was no significant difference between fed and fasting rats. In the first hour after $\left[{ }^{3} \mathrm{H}\right] \mathrm{TdR}$ injection the LI were concentrated in the cells at bottom and middle positions (Figure 3A). At the other intervals there was a displacement of cells towards the top, mainly at $19 \mathrm{~h}$ (Figure 3D). In order to clarify this aspect, the crypts were divided into regions and their LI are presented in Table 2. The LI were significantly lower at the top position $1 \mathrm{~h}$ after $\left[{ }^{3} \mathrm{H}\right] \mathrm{TdR}$ injection in both fed and fasting rats. After $19 \mathrm{~h}$, the LI of middle and top positions were equally higher than the LI from the bottom in the fed animals, whereas in fasting rats the middle position had a higher LI than the bottom or top position (Table 2), suggesting a very slight delay in cell migration in the crypt of fasting rats.

\section{Cell cycle parameters}

Figure 4 shows the decrease of the mean grain number of labeled cells as a function of time after $\left[{ }^{3} \mathrm{H}\right] \mathrm{TdR}$ injection. Linear regres- 


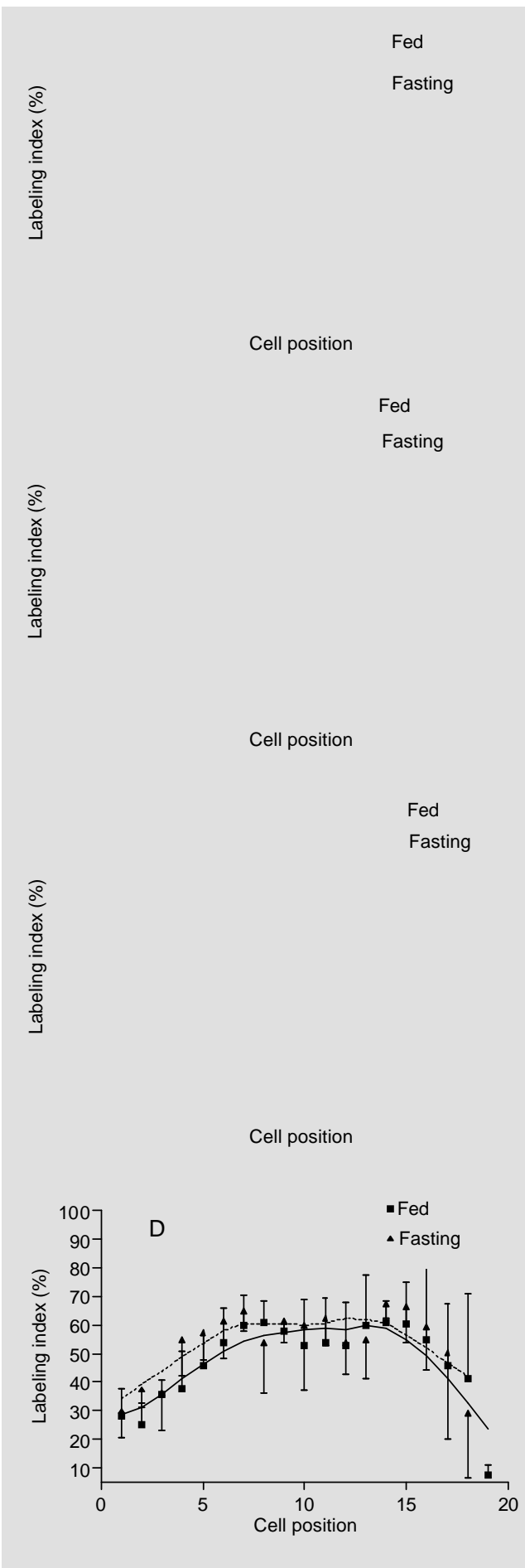

Figure 3 - Labeling index distribution curves (\%) for each cell position along a crypt-column in fed and fasting rats at different times after injection of $\left[{ }^{3} \mathrm{H}\right] \mathrm{TdR}(A$ at $1 \mathrm{~h} ; B$ at $8 \mathrm{~h} ; C$ at $13 \mathrm{~h}$, and $D$ at $19 \mathrm{~h}$ ). Each point represents the means \pm SD of 20 crypts per animal. sions were obtained for the number of grains over labeled cells (that gives the duration of the cell cycle, Tc) and for the number of grains over all cells (that gives the potential cell cycle, Tpot), for each group of fed or fasting rats. The lines fit the experimental data significantly (the probability that the data are merely linearly correlated by chance was less than 0.001 for 3 curves; in the regression of Tpot for fasting rats the significance was 0.02 ). Linear regression analysis showed a significant decrease of grain count.

Comparison of the slopes of the two re-
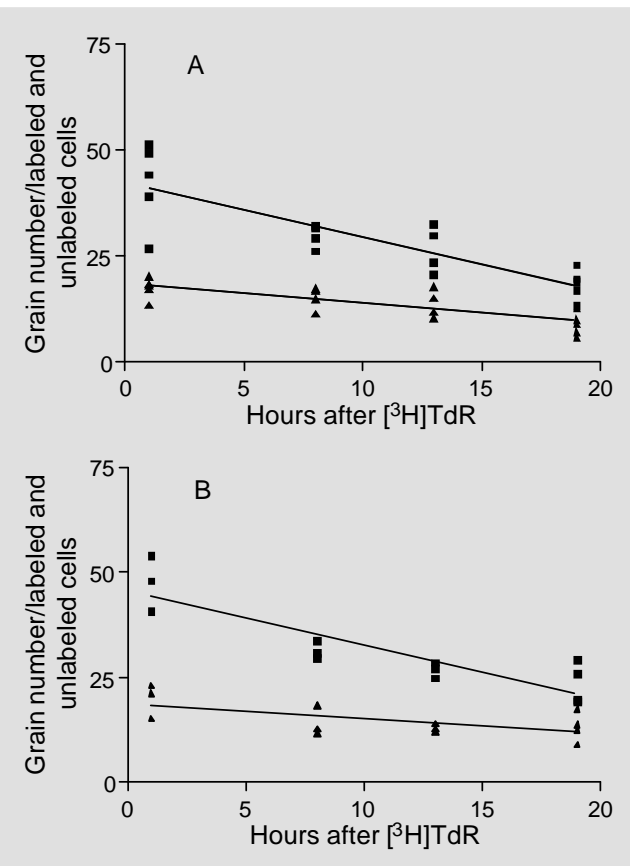

Table 1 - Labeling indices (LI) of crypts obtained 1, 8 , 13 and $19 \mathrm{~h}$ after injection of $\left[{ }^{3} \mathrm{H}\right]-\mathrm{TdR}$ in fed and fasting rats.

The results are reported as means $(\%) \pm$ SD. The number of animals is given in parentheses. ${ }^{*} \mathrm{P}<0.05$ compared to $\mathrm{LI}$ at $1 \mathrm{~h}$ (Tukey test).

\begin{tabular}{cccc}
\hline $\begin{array}{l}\text { Time } \\
\text { after } \\
\text { fasting }\end{array}$ & $\begin{array}{c}\text { Time } \\
\text { after } \\
{\left[{ }^{3} \mathrm{H}\right] \mathrm{TdR}}\end{array}$ & \multicolumn{1}{l}{ Fed } & Fasting \\
\hline $6 \mathrm{~h}$ & $1 \mathrm{~h}$ & $38.7 \pm 4.89(6)$ & $34.6 \pm 5.11(4)$ \\
$13 \mathrm{~h}$ & $8 \mathrm{~h}$ & $49.8 \pm 7.55(4)$ & $40.3 \pm 9.41(4)$ \\
$18 \mathrm{~h}$ & $13 \mathrm{~h}$ & $51.5 \pm 3.35^{*}(4)$ & $48.8 \pm 3.37(3)$ \\
$24 \mathrm{~h}$ & $19 \mathrm{~h}$ & $48.1 \pm 7.36(5)$ & $50.4 \pm 7.54^{*}(6)$
\end{tabular}

Figure 4 - Decrease in the grain number of labeled (squares) and unlabeled cells (triangles) in the jejunal epithelium as a function of time after pulse labeling with $\left[{ }^{3} \mathrm{H}\right] \mathrm{TdR}$ in the fed group $(\mathrm{A})$ and in the fasting group (B). Each point represents the mean of 20 crypts per animal. $A, \mathrm{~N}=18$; $B, \mathrm{~N}=13$. 
gression lines (Tc of fed and fasting rats) showed no significant difference. Also, no difference was found between the slopes of the Tpot regression lines of fed and fasting rats. Table 3 shows the Tc and Tpot derived from the linear regressions and the growth fraction derived from these values. The calculated error for the growth fraction was $10 \%$ for fed animals and $7.9 \%$ for fasting animals, so that the difference between the growth fractions was at the limit of significance.

\section{Migration in the villus}

Cellular migration in the villus is shown in Table 4. Fasting significantly depressed migration by $8 \%$.

\section{Discussion}

The present results demonstrate that progressive fasting causes a delay in cell migration in the villi of weanling rats. Mitotic activity continued in the crypt in the absence of migration in the villus. There was a reduction in the growth fraction, but with this treatment both cell migration and cell cycle duration in the crypts were unchanged.

The progressive fasting utilized in this work did not modify the proliferative indices of the jejunum. We have already demonstrated that $20 \mathrm{~h}$ of fasting did not change the DNA synthesis index in the jejunum of 18day-old rats, whereas in 14-day-old suckling

Table 2 - Labeling indices (LI) by crypt region of the jejunal epithelium at 1 and $19 \mathrm{~h}$ after injection of $\left[{ }^{3} \mathrm{H}\right] \mathrm{TdR}$ in fed and fasting rats.

The results are reported as means (\%) \pm SD. The number of animals is given in parentheses. a $<0.05$ compared to the $\mathrm{LI}$ of other regions (Tukey test); $\mathrm{b}_{\mathrm{P}<0.05}$ compared to bottom LI (Tukey test).

\begin{tabular}{lccccc}
\hline & \multicolumn{3}{c}{$1 \mathrm{~h}$} & \multicolumn{2}{c}{$19 \mathrm{~h}$} \\
\cline { 2 - 4 } \cline { 5 - 6 } & \multirow{2}{*}{ Fed (5) } & Fasting (4) & & Fed (5) & Fasting (4) \\
\hline Bottom & $41.5 \pm 10.7$ & $34.8 \pm 4.6$ & & $33.8 \pm 6.5^{\mathrm{a}}$ & $40.5 \pm 5.8$ \\
Middle & $58.4 \pm 8.9$ & $50.0 \pm 9.1$ & & $56.2 \pm 8.0$ & $65.5 \pm 14.5^{\mathrm{b}}$ \\
Top & $22.6 \pm 8.6^{\mathrm{a}}$ & $18.4 \pm 2.5^{\mathrm{a}}$ & & $50.8 \pm 12$ & $52.0 \pm 6.7$
\end{tabular}

Table 3 - Cell cycle time (Tc), potential doubling time (Tpot) and growth fraction (GF) of the jejunal epithelium in fed and fasting weanling rats.

\begin{tabular}{lccc}
\hline Treatment & Tc $(\mathrm{h})$ & Tpot $(\mathrm{h})$ & GF $(\%)$ \\
\hline Fed & 16.5 & 20.0 & $77 \pm 10.0$ \\
Fasting & 17.8 & 26.7 & $59 \pm 7.9$
\end{tabular}

rats there was an inhibition of proliferative activity in all intestinal segments (Palanch $\mathrm{AC}$ and Alvares EP, unpublished results). In the jejunum of 12-day-old fasting rats, however, the proliferative activity was not different when determined by liquid scintillation spectrometry, but migration into the villi was also retarded after fasting (16).

A decrease in proliferative indices occurs in the small intestine of adult rats submitted to starvation (11,17-20). An increase in the duration of the cell cycle usually follows these hypoproliferative changes $(11,19)$. In weanling rats, there was no difference in cell cycle duration between fasting and fed pups, and therefore no difference in proliferative activity.

The method of choice for estimating cell cycle parameters was the modified grain count halving method (12). The values obtained by this method compare well with the parameters obtained by the well-known method of the frequency of labeled mitoses (FLM), and in the present case, the former showed some advantages. The time of the experiment could be relatively shorter than for FLM, so we were able to keep the fasting animals safe from stress for longer periods. Also, the grain count halving method allows an insight into the growth fraction. The utilization of young growing animals, which have slower migration rates and no loss of cells in the crypts, provided a reliable model for using this method.

The average duration of the cell cycle of fed and fasting weanling rats was within the range obtained by other methods. In the duodenum of 16-day-old rats the Tc is $17.7 \mathrm{~h}$ (5) and in the ileum the Tc is between $18.6 \mathrm{~h}$ 
and $12 \mathrm{~h}$, as described for 8- and 28-day-old rats, respectively (4). Through the grain count halving method, a Tc of $18.8 \mathrm{~h}$ was estimated in ileal crypts of young adult mice (21).

The other parameter obtained by the grain count halving method was the growth fraction that was lower in fasting than in fed rats. However, due to the estimated error the difference was not too large. Other growth fractions described for young rats are close to our results, about $64 \%$ and $66 \%$ for the duodenum of 6- and 22-day-old rats (5). In the ileum the values are 55\% (8 days) and $97 \%$ (28 days). In the jejunum of adult rats, the growth fraction remained constant during starvation (11), in contrast to the present study. Despite this fact, the number of cells in the crypts was not different between fed and fasting rats. The mean value of 200 cells per crypt for 18-day-old rats is in the range of the results found for 16- (124 cells) and 22day-old rats (261 cells) in the duodenum (5). Thus, the reduction in the growth fraction may be considered the first effect of fasting on proliferative activity, even if not yet reflected in the proliferative indices and cell cycle duration.

In regard to cell migration, the results showed a significant delay only in the villus, that might have been related to diminished cell loss in the fasting condition. The shedding of cells on the villus tip can only rarely be found in histological sections of small intestine. Also, the loss of cells is the most difficult parameter to be accurately measured by cell kinetic methods. However, it has been widely accepted that food causes attrition at the villus tips. Indirect evidence of the influence of a solid diet on cell proliferation in the jejunum of weanling rats was provided by Al-Nafussi and Wright (22), who suggested that the cell loss was markedly lower in the non-weaned group (rats prevented from weaning, with no solid food) during the third week of life.
Table 4 - Cell migration in the villi of fed and fasting rats $19 \mathrm{~h}$ after injection of $\left[{ }^{3} \mathrm{H}\right] \mathrm{TdR}$.

The results are reported as means \pm SD. The number of animals is given in parentheses. ${ }^{*} \mathrm{P}<0.05$ compared to the fed group (Student $t$-test).

\begin{tabular}{lcc}
\hline & Fed (5) & Fasting (6) \\
\hline $\begin{array}{l}\text { Cell migration } \\
\text { rate }(\mathrm{h})\end{array}$ & $0.5 \pm 0.06$ & $0.3 \pm 0.06^{*}$ \\
$\begin{array}{l}\text { Position of } \\
\text { labeled cell }\end{array}$ & $9.4 \pm 1.23$ & $6.2 \pm 1.14^{*}$ \\
$\begin{array}{l}\text { Height of } \\
\text { labeled cell (\%) }\end{array}$ & $21.8 \pm 2.49$ & $13.7 \pm 2.09^{*}$
\end{tabular}

The mechanism suggested for cell migration in the villus (1) involves smooth muscle contraction in the lamina propria of the villi. So, during fasting, with the absence of food in the lumen, less movement is expected in the villi. This is coherent with the described reduced rate of migrating cells in the villi of fasting animals. Such an observation was possible due to the use of mild (5 h) and progressive fasting.

Studies in recent years have identified the role of growth factors in cell proliferation (23) and also in cell migration (24). Hepatocyte growth factor, for instance, has been shown to enhance cell migration but only in in vitro models of intestinal restitution (23). Nevertheless, since inhibition of protein synthesis, at least in adult rats, did not stop cell migration in the villi (1), the true action of growth factors on cell migration in vivo remains to be demonstrated.

The relevance of this study lies in the demonstration that the absence of luminal food exerts its first effect upon the villus, interfering with migration. In the crypt of fasting rats, where some cells left the growth fraction, this effect is more likely to be due to the absence of nutritional elements. In both cases growth factor influences are not excluded, but the mechanism of action may be independent. 


\section{References}

1. Kaur P \& Potten CS (1986). Effects of puromycin, cycloheximide and noradrenaline on cell migration within the crypt and on the villi of the small intestine. A model to explain cell movement in both regions. Cell and Tissue Kinetics, 19: 611-625.

2. Kaur P \& Potten CS (1986). Cell migration velocities in the crypts of the small intestine after cytotoxic insult are not dependent on mitotic activity. Cell and Tissue Kinetics, 19: 601-610.

3. Koldovský O, Sunshine P \& Kretchmer N (1966). Cellular migration of intestinal epithelia in suckling and weaned rats. Nature, 212: 1398-1400.

4. Klein RM (1977). Alteration of cellular proliferation in the ileal epithelium of suckling and weaned rats: the effects of isoproterenol. Cell and Tissue Kinetics, 10: 353-364.

5. Yeh KY (1977). Cell kinetics in the small intestine of suckling rats. I. Influence of hypophysectomy. Anatomical Record, 188: 69-76.

6. Henning SJ (1981). Postnatal development: coordination of feeding, digestion and metabolism. American Journal of Physiology, 241 (Gastrointestinal and Liver Physiology, 4): G199-G214.

7. Herbst JJ \& Sunshine P (1969). Postnatal development of the small intestine of the rat. Changes in mucosal morphology at weaning. Pediatric Research, 3: 27-33.

8. Palanch AC \& Alvares AP (1998). Feeding manipulation elicites proliferative responses in the gastrointestinal tract of suckling and weaning rats. Brazilian Journal of Medical and Biological Research, 31: (in press).
9. Kopriwa BM \& Leblond CP (1962). Improvements in the coating technique of radioautography. Journal of Histochemistry and Cytochemistry, 10: 269-284.

10. Kaur P \& Potten CS (1986). Circadian variation in migration velocity in small intestinal epithelium. Cell and Tissue Kinetics, 19: 591-599.

11. Aldewachi HS, Wright NA, Appleton DR \& Watson AJ (1975). The effect of starvation and refeeding on cell population kinetics in the rat small bowel mucosa. Journal of Anatomy, 119: 105-121.

12. Bassukas ID \& Schultze-Maurer B (1987). A modification of the grain halving method for detailed analysis of cell kinetic parameters. Cell and Tissue Kinetics, 20: 527537.

13. Yeh KY, Yeh M \& Holt PR (1991). Intestinal lactase expression and epithelial cell transit in hormone-treated suckling rats. American Journal of Physiology, 260 (Gastrointestinal and Liver Physiology, 23): G379-G384.

14. Zar JH (1996). Biostatistical Analysis. 3rd edn. Prentice Hall, Englewood Clifts, NJ.

15. Sokal RR \& Rohlf FJ (1995). Biometry. 3rd edn. WH Freeman, New York,.

16. Nsi-Emvo E, Jourdainne-Foltzer C, Raul F, Gosse F, Duluc I, Koch B \& Freund JN (1994). Precocious and reversible expression of sucrase-isomaltase unrelated to intestinal cell turnover. American Journal of Physiology, 266 (Gastrointestinal and Liver Physiology, 29): G568-G575.
17. Hooper AF \& Blair M (1958). The effect of starvation on epithelium renewal in the rat duodenum. Experimental Cell Research, 14: 175-181.

18. Rose PM, Hopper AF \& Wannemacher RW (1971). Cell population changes in the intestinal mucosa of protein-depleted or starved rats. Changes in mitotic cycle. Journal of Cell Biology, 50: 887-892.

19. Altmann GG (1972). Influence of starvation and refeeding on mucosal size and epithelial renewal in the rat small intestine. American Journal of Anatomy, 133: 391-400.

20. Goodlad RA \& Wright NA (1988). Epithelial cell proliferation and intestinal absorptive function during starvation and refeeding in the rat. Clinical Science, 74: 301306.

21. Chwalinsky S \& Potten CS (1991). The decay of radioautographic grain number over crypt base columnar cells in murine ileum as a measure of their generation time. Cell Proliferation, 24: 21-31.

22. Al-Nafussi Al \& Wright NA (1982). Cell kinetics in the mouse small intestine during immediate postnatal life. Virchows Archiv (Cell Pathology), 40: 51-62.

23. Podolsky DK (1993). Regulation of intestinal epithelial proliferation: a few answers, many questions. American Journal of Physiology, 264 (Gastrointestinal and Liver Physiology, 27): G179-G186.

24. Dignass AU, Lynch-Devaney K \& Podolsky DK (1995). Hepatocyte growth factor/scatter factor modulates intestinal epithelial cell proliferation and migration. Biochemical and Biophysical Research Communications, 202: 701-709. 